\title{
THE INFLUENCE AND THE ADVANTAGE OF AMERICAN HIP HOP TO THE RISING ASIAN RAPPERS
}

\author{
Mayza Nisrin Abielah \\ e-mail: mayza.abielah@gmail.com
}

\begin{abstract}
Cultural imperialism aims at how dominant culture affects other cultures to gain control of certain cultures and create the view that their dominant culture is the center for all countries in the world, which will create uniformity around the world. Therefore, this study will discuss how Asian rappers are influenced by American hip hop culture and how they benefitted from their careers' success. The theory used in this study is cultural imperialism by John Tomlinson to see the influence of cultural imperialism in American hip hop culture to Asian rappers. The method used in this study is qualitative research by Creswell. The result shows that America's cultural imperialism influences Asian Rappers by adopting its culture, language, and style of American hip hop. However, its influence is not harmful since the Asian rappers use this to gain more recognition from people, especially in Western, and to be accepted in representing Asian immigrants in the United States.
\end{abstract}

Article information

Keywords: American hip hop; Asian rappers; cultural imperialism; hibridity; globalization; media imperialism; postcolonialism

DOI $\quad$ : https://doi.org/10.22146/rubikon.v7i1.62506

Available at https://jurnal.ugm.ac.id/rubikon/article/view/62506

This work is licensed under a Creative Commons Attribution-ShareAlike 4.0 International License

\section{INTRODUCTION}

The emergence of globalization influences the development of human civilization, especially in the 21 st century. One of the drivers of globalization is technological progress that continues to grow over time. In other words, the phenomenon of globalization has always been associated with increasing technological advancements that have a significant impact on society, which can cause global issues to emerge amid the community. The ease of communication in globalization and the rise of immigration from one country to another have made cultural hybridity spread in many countries. Moreover, the existence of globalization removes the boundaries between cultures that previously have a limitation in communicating with each other.

Furthermore, as the internet is a technology product that has a vital role in 
long-distance communication, people from Asia can communicate with Europeans and people from the United States quickly using the internet. However, the colonization of culture in the modern era can be done many miles away by only using technology. Therefore, in the age of globalization, the First World country's cultural imperialism can be easily dominating other countries because their culture and products are easily and quickly popular throughout the world through technology.

With the existence of technology to exchange the information, the developed countries can efficiently distribute their culture and arts through sophisticated technology that will influence other countries' culture and arts, which makes them imitate and mix their culture with the other cultures. As Kraidy explains in his article, Hybridity and Cultural Globalization (2002) has hybridity became the master trope across many spheres of cultural research as several studies have employed hybridity to describe mixed genres and identities (Kraidy, 2002). Defta Ananta Dasfriana also discusses a study about Asian hip hop in the United States in her undergraduate thesis entitled Komodifikasi dan Universalisme Budaya dalam Asian Hip Hop di Amerika Serikat oleh 88rising. She discussed the universalism of Asian Hip Hop culture using international relations perspective and critical constructivism theory and concludes that the commodification of hip hop culture by Asians will decrease both cultures' essence and create a new sense of identity (Dasfriana, 2019).

Hip hop culture, which has recently entered the world's mainstream culture, is also doing cultural imperialism. Hip hop is originally an underground culture that originated from African American, Afro Caribbean and Latino men in the United States in the South Bronx in the 1970s as a way to accommodate the oppressed African Americans to express their voices and express their disappointment and emotion through the music as an oppressed race, social class, and economic class in the United States (Forman, 2010). Moreover, the emergence of rappers from other races in other countries raises many questions. Hip hop culture is currently very much loved by young people from Asia, and it triggers the existence of Asian rappers, especially in the United States market. Therefore, how much they are influenced by hip hop culture through the media will be discussed in this article.

Asian artists' existence in hip hop culture is an example of cultural imperialism in media and culture. However, American hip hop influences to the Asian rappers affect the presence of Asian American identity in the United States and make them represent themselves in the West through hip hop. This East meets West phenomenon turns into advantages for Asian rappers. Therefore, this article focuses on cultural imperialism, especially in the influences of American hip hop to Asian rappers, especially in the case of Keith Ape (Korean rapper), Rich Brian (Indonesian rapper), and Kohh (Japanese rapper). In that essence, this article focuses on answering two research questions, how American hip hop culture influences Asian rappers and how those Asian rappers take advantage of American hip hop culture.

This article uses the perspective of postcolonialism and globalization and applies the theory of cultural imperialism by John 
Tomlinson (2002). As Tomlinson said that globalization facilitates global communication and the spread of cultural perspectives through new media and technological advancements, and some argue that globalization is, therefore, a tool of Cultural Imperialism (Tomlinson, 2002). In Tomlinson (2002), Fred Fejes (1981) discusses that a mass of detailed descriptions of the global operations of the media industries, focusing on the control exercised by the Western transnational corporations over the flow of information and the dissemination of the media products worldwide (Tomlinson, 2002). Furthermore, because the cycle of media imperialism is centered in the Western transnational corporation, those who get the impact of media imperialism are often countries outside of Western countries.

Cultural imperialism is the long term influence or dominance of one nation's culture over others. As Herbert Schiller (1976) defines cultural imperialism as "the sum of the process by which a society is brought into the modern world-system and how its dominating stratum is attracted, pressured, forced, and sometimes bribed into shaping social institutions to correspond to the values and structures of the dominating center of the system" (Schiller, 1976). This explanation shows that cultural imperialism is an attempt done by a culture to dominate other cultures by slowly entering different cultures' cultural values in any way.

In carrying out cultural imperialism, the dominant culture uses various methods, such as economics, politics or power, culture, media, language (lingua franca), and literature. Chris Barker (2008), in his book Cultural Studies: Theory and Practice, says that "the cultural homogenization thesis proposes that the globalization of consumer capitalism involves a loss of cultural diversity. It stresses the growth of 'sameness' and a presumed loss of cultural autonomy which refers to cultural imperialism" (Barker, 2008). In the globalization era, cultural imperialism aims to dominate the other cultures and become the standard used in other countries, particularly in the Third World countries through the media, politics, economics, and even culture. Dominant culture tries to universalize everything, so indigenous people will eventually forget their cultural diversity.

Following the earlier statement, Schiller describes the transnational media as "inseparable elements in a worldwide system of resource allocation generally regarded as capitalistic," which "create and reinforce their audiences' attachment to the way things are in the system overall." He employs a broad notion of culture as a 'way of life,' and what is significant about this way of life is the centrality of 'the system' within it. It is seen as shaping how things are at all levels of Western societies, from the militaryindustrial complex to the personal existential experience of citizen-consumers (Tomlinson, 2002). Tomlinson emphasized that culture here can involve all aspects of human life. Therefore, if other cultures influence someone, they will experience significant changes in their lifestyle.

As previously explained in the introduction, American hip hop culture also implements cultural imperialism through the media since it currently enters the mainstream media. New rappers from other races and countries are forced to follow the American hip hop culture pattern. Start from 
their rap lyrics' language to their lifestyle and style like hip hop singers or rappers. Rappers from other countries seem to have to follow American rappers' ways because hip hop originates from the United States and is oriented to American hip hop as a benchmark in becoming a rapper.

Cultural imperialism is the effort of dominant cultures to impose their ideologies and culture to the Third World countries through any cultural aspects. In another essence, in postcolonial discourse, Said (1994) says that Cultural Imperialism is seen as the cultural legacy of colonialism and is often attributed to Western hegemony (Said, 1994). Said argumentation is supported by Schiller (1976), which argues that U.Scontrolled corporations dominate the global communications industries. He points out to the interlocking network that connects U.S television, defense sub-contractors, and the federal government. They act as vehicles for corporate marketing and a general 'ideological effect' that purportedly produces and reinforces locals' attachment to U.S capitalism (Barker, 2008). It indicates the dominance of American culture, which began to become dominant in many countries. An example can be seen from the spread of American brand products such as McDonald's, Starbucks, Pizza Hut, and universally distributed American media such as music, American TV Series, movies, etc.

Music is one of the massive media products produced by Hollywood. Rap Music, EDM, R\&B, Pop, and Rock are music genres originating from America. Music produced by Western countries like the United States quickly becomes global popular music throughout the world because it is universally distributed. It affects the culture of other countries and raises the emergence of rap singers in each country. In the 1960s and 1970s, the domination of global music production by a group of multinational corporations based in Britain and the United States, issuing records mainly made by actions from those countries, provided yet another instance of American cultural hegemony, reinforced by the vestiges of an older empire (Hesmondhalgh, 1995).

The expanse of music globally makes musicians free to access the songs from anywhere in different languages through social media platforms, youtube, and music streaming applications to freely listen to songs from various countries. It is a form of media imperialism where global top hits songs that mostly came from the United States can easily influence the audience and inspire other musicians to create works similar to that. Furthermore, by making the similar music, the music around the world will sound the same and have the same characteristics.

Rap music is a music genre developed in the United States by inner-city African Americans in the 1970s which consists of stylized rhythmic music that commonly accompanies rapping, a rhythmic and rhyming speech that is chanted. Although Hip Hop or Rap music originally came from Africa as a part of hip hop culture, the United States managed to produce successful Rap music. Hip hop and rap are not the same, in addition to hip hop as the subculture among contemporary Black youth and Rap as one method of delivering messages to the hip hop society (Tomlinson, 2002).

Bynoe explains that Cultural imperialism is identical to the "world culture" in which 
the dominant culture imposes its beliefs, values, and styles on others. The globalization of hip hop culture also does this. The youth worldwide must follow the United States' hip hop culture, which the United States has exported through media and technology (Bynoe, 2002). Therefore, in this case, to find out how much influence the American hip hop culture has on Asian rappers, it is necessary to look at which sides Asian rappers use from the American hip hop culture to their hip hop.

Thus, this study uses the theory of cultural imperialism by John Tomlinson to see how American hip hop affects Asian rappers and how Asian rappers benefitted. The method used in this study is qualitative research by Creswell as qualitative research means for exploring and understanding the phenomena in society. The research process involves emerging questions and procedures, and data collected in observation through many sources, and the analysis comes from the researcher's interpretation (Creswell, 2013). In discussing this study, the writer uses the reliable online sources of data to get the information and analyzing how Asian rappers in the United States influenced by American hip hop and how Asian rappers benefitted from it.

\section{DISCUSSION}

\section{From English to Dreadlocks}

The three Asian rappers out of many other Asian rappers currently famous in the media are Keith Ape (Korean rapper), Rich Brian (Indonesian rapper), and Kohh. (Japanese rapper). Keith Ape and Rich Brian are the Rappers under the 88rising label, while Kohh often collaborates with artists from 88rising. 88rising, formerly known as
CXSHXNLY is a record label based in the United States. It is an Asian-focused recording label. Theirs are the voices of not just a generation but of an entire race who have been woefully under-represented in Western music and the visual arts (Glasby, 2018). The label is a record label representing Asian artists such as Rich Brian (Indonesia), Keith Ape (South Korea), and many others.

Dongheon Lee (As proficiently known as Keith Ape) is a Korean hip-hop artist 88rising first in 2015. He was famous for his single "잊지마" ("It G Ma"), which was described by critics of The New York Times as "a cross-cultural curiosity and also a clear inheritor of Southern rap rowdiness that requires no translation" (Pareles et al., 2015). Soon after Keith Ape, 88rising discovered several artists from Asia, including a young Indonesian rapper named Brian Imanuel, known as Rich Brian or Rich Chigga. They also found a Japanese-Australian singer and producer named George Miller (as known as Joji), formerly a Youtuber and Internet meme creator, and a Chinese hip-hop group called Higher Brothers (Zhang, 2018).

Rich Brian, an Indonesian rapper with Chinese roots who became famous through the internet. In February 2016, Brian uploaded the now-infamous Dat \$tick video to the platform, rapping with a doomy trap beat while wearing a bumbag and a pink polo shirt. It blew up, and it has 159 million views as of September 2020, putting 16-year-old Brian, who is now 20 years old, in the spotlight for its visual absurdity, but also for his moniker at the time, Rich Chigga, and the use of the $\mathrm{N}$-word in the lyrics, which he censored after attracting criticism (Glasby, 
n.d.). Dat \$tick song of Rich Brian is using English and since the existence of the $\mathrm{N}$ word in the lyrics which he used as he imitated how American rappers that mostly African American used the word, it can be implied that the influence of American culture, primarily through the internet, is quite significant to the Asian rappers.

The existence of 88rising, which accommodates Asian hip hop artists in the United States, has made the artists famous worldwide. It indicates that their target market is not only in Asia but also globally. However, to reach this market, Asian hip hop artists' contents must use a universal language, which is English. Even though they often mix the language with their root's language, but it can be said that one of the influences of the American hip hop to the Asian rappers is the language used in their artworks.

Some of the lyrics of Keith Ape, Rich Brian, and Kohh's raps are in English. Even though Keith Ape and Kohh still often use their language and add some English words to the lyrics. For Rich Brian, it is a rarity for his lyrics to include the Indonesian language in the lyrics. He has produced some singles and an album named Amen. The album consists of fourteen songs, and all the songs are in English. Rich Brian song 'Glow Like Dat':

I be on my Mac Demarco shit, break my heart then smoke a cig, even put some cloves in it

Don't test me because my skin ain't thick,

hit your walls I need my fix, pull up on you need

Way more witchu had too much of these hoes
Never told you bout the summer that I spent with my bros

From the lyrics above, it can be seen that Rich Brian mostly and entirely uses English. That way, it can be seen that Rich Brian's target market is global. Same with Rich Brian, Keith Ape's lyrics are in English regardless that he is Korean. Even though some of his songs are in Korean, but mostly mix in English since he joined 88rising. His song entitled Ninja Turtle' lyrics are like this:

Come fuck with me, fuck with me, 그냥 내게 줘 머리

나는 위, 너무 위, 가까워보여 하늘이

Dark stout, Russian cream, 생긴건 마치

나뭇잎

Sippin' lean, smoke cookies, 난 느려져

거북이

거북이, 거북이, 거북이, 거북이,

새벽두시

Pop 2 pills, feel like ninja turtle, bitch

Bandana, mask on me, like i'm ninja turtle, bitch

Money counting, like machine, my pocket drippin' blue cheese, ay

Unlike the two rappers from the 88rising label, Kohh, whose real name is Yuki Chiba is under the label Gunsmith Production, based in Japan. He has been working with the artist from 88rising like Keith Ape and an artist from the United States, Frank Ocean. $\mathrm{He}$ gained worldwide recognition from the featured in Keith Ape's hit It G Ma in 2015 (Glasby, 2017). Even though Kohh is not the rapper under the 88rising label, he also often collaborates with artists from the label. Kohh has been in the Japanese hip hop industry, starting in 2008 (Kalisu, 2017). Therefore, Kohh's name in the hip hop industry is not 
inferior to the existing artists under 88rising. That being said, Kohh, a Japanese rapper, is also reaching a global audience just like Keith Ape and Rich Brian. Like Keith Ape, the lyrics used by Kohh are the mixture of his native language, namely Japanese and English. Even so, the use of English contained in their songs is mostly English slang, cursed, and sexual words, which they often put in their song lyrics.

Bad bitch 嫌いじやない

でもお互い好きにはならない

楽しむだけ

深く考えない関係

I got pussy in my iPhone

American hip hop artists mostly use inappropriate words because rappers use "freestyling," "flow" or wordplay. In this way, the rappers use whatever rhythmic words appear in their minds. It influences the rappers from other countries to use mostly inappropriate slang words. The word that is commonly used in English, even though most of the lyrics are in a different language, but the rappers still use English to express themselves using inappropriate words that seem to be the standard of rap. The quote from the lyrics above points that the English words that are identical to their rap lyrics are vulgar slang words like 'bitch'. "Fuck", "pussy", and "shit," which are words that have an impolite meaning and are often spoken by young people in the United States.

In representing Asian rappers in global music, Rich Brian, Keith Ape, and Kohh must use English or mix English and follow American rap music culture itself. English and American rap have become global popularity standards for every rapper. It indicates that the dominant culture is adopted by people from other cultures that cause uniformity. By debuting in the United States, they could represent Asian rappers in the Western Music industry as Asian artists also have to live in the United States for a long time since the label is based in the United States.

Nevertheless, with the perspective of cultural imperialism, in representing Asian rappers in global music, they must use English and follow the culture and American rap music trend. English language and American rap have become global popularity standards for every rapper. That way, a dominant culture here is used by people from other cultures, which later causes uniformity to be accepted by most countries. The Influence of American Rap music in Asian Rappers was occurred a long time ago, in Indonesia alone, even though many rappers in Indonesia rap in the Indonesian language. However, as the era of globalization has been increased, many Indonesian rappers rap in English as they want to get more 'popular' globally to reach a broader market.

Besides English, American Hip Hop also influences Asian rappers' wearing certain clothes and hairstyles. Hip-hop style clothes also influenced Asian rappers in their clothes and accessories such as large pants and chain gold necklace. Besides, this influence is significantly visible through Keith Ape's style as dreadlocks, which originally belong to African American culture, once become Keith Ape's signature looks. Even though this has attracted much attention and controversy because it is considered inappropriate for Non-African Americans to have a dreadlocks hairstyle and is considered disrespectful to the culture, but not a few also accept Keith Ape's dreadlocks hairstyle and even inspire other Asian youth who are 
exposed to hip hop culture. This phenomenon points out that other cultures will imitate the culture distributed globally by the United States.

Furthermore, according to Tai (2018), the embodiments of hip hop and perceptions of African-American culture are more reflective of stereotypes and diversity, especially in East Asian countries (Tai, 2018). However, this can be said to be the result of cultural imperialism where the American hip hop culture itself is commercialized throughout the world and causes people from other countries to imitate that culture. Therefore, some people from other countries imitate American hip hop's style without researching the meaning of the culture. As Tomlinson (2002) explains, cultural imperialism in this era of globalization causes uniformity or cultural homogenization, which designates how products imported from the West will affect other countries (Tomlinson, 2002). In this case, the hip hop culture that has become a role model for hip hop artists in the world is American hip hop culture. Using the English language and following the American hip hop artist's style as the standard of hip hop culture led to cultural universality. Not only in terms of art and products, the influence of the American hip hop culture also has an impact on the way of life of the Asian rappers.

\section{The Advantage of American Hip Hop to the Asian Rappers}

Previously, it was explained that American hip hop's imperialism made Asian rappers follow the United States' standards in becoming a rapper by using English and imitating the style of the American hip hop culture. However, Asian rappers do not stop at their song lyrics to introduce their native culture. Precisely by being Asian rappers who have a global market, they are still promoting their native culture in other ways, acknowledging and being proud of their culture. With the 88rising label, it makes it easier for Asian rappers to promote their origins' culture.

Historically, Asian American or Asian rappers have appeared since the 2000s with MC Jin, who at that time claimed to be the first Asian rappers in the United States. In the meantime, the 88rising label has gathered some Asian artists as their focus on the hip hop industry. Their hybrid culture's root influence originated from the founder of the label 88rising itself, namely Sean, an Asian American of Japanese and Korean descent who lives in San Jose (Zhang, 2018). Sean anticipated that the industry's next trend would be hip hop music (particularly trap: a hip hop subgenre initially from South America) from his background and music sense. The genre is strongly affected by the drug dealing, gangster, violence phenomenon from its origin: a small part of Atlanta where people are struggling on the street and live through drug dealing, the name trap is the word used to define this activity (Leonard, 2017).

As rappers from the 88rising label that promotes Asian rappers, Keith Ape and Rich Brian are considered representatives of Asian rappers in the West, primarily Asian immigrants in the United States. Likewise, with Kohh, who often collaborates with artists from 88rising, as Japanese rappers, he represents Japan in hip hop music and is well known by many people. Although some Asian Americans think that "it doesn't matter 
how close they come to mainstream success, they must first confront an idea that they don't belong in hip-hop." (Lee, 2018).

People's perspectives on Asian rappers are not all positive. Some people feel that hip hop culture is just the United States' culture, especially African Americans. Nevertheless, over time, Asian rappers began to be accepted in the United States and had their fanbases. That way, Asian rappers made American hip hop culture a borderless culture and managed to cross the boundaries between cultures. It can be said that 88rising helps Asian artists to express their creativity in the worldwide market.

The label promotes their artists' original culture through their artist, such as how their artists talked about their native food culture and several other topics on several youtube channels. Even though it is not being represented in most of the rappers' lyrics, the label is still considering to promote the cultural roots of the artists. Sean's goal in forming the label and gathering Asian artists is because he wants to represent the Asian immigrant in the United States, and he also wants to represent all immigrants in the United States so that when they saw an Asian singer, they felt more connected to the singer. Besides, Asian rappers can also be accepted among other westerners because they combine western and Asian cultures. Therefore Asian rappers are no less competitive with African American and Anglo American rappers because Asian rappers also have their audiences, distinctions, and other unique traits.

Therefore, the imperialism carried out by the American hip hop culture also benefits Asian rappers, because nowadays, hip hop has become one of the mainstream cultures in the media which are loved by many young people. It provides an opportunity for Asian rappers to be better known globally and indirectly introduce their country of origin. Like Rich Brian, as before, many Americans did not know the State of Indonesia. He also took part in introducing Indonesia because his fan base in the United States is quite large.

\section{CONCLUSION}

Cultural imperialism carried out by the United States successfully influenced other cultures. In this case, Asian rappers adopted American hip hop culture by using English in the lyrics of their songs and demonstrating American youth's culture in their music videos. However, Asian rapper and his management, 88rising, are not solely using the $100 \%$ American hip hop culture but combining them with their Asian culture. By this, it can be said that these Asian rappers use and utilize American cultural imperialism to support their careers, representing immigrants in the United States so that they can also be accepted among Western audiences.

It can be seen that a lot of the influence Asian rappers have taken from the American hip hop culture. Like how they use English lyrics, which are mostly vulgar as contained in the lyrics of songs from Keith Ape, Rich Brian, and Kohh. Besides, they also imitated how American rappers dressed and styled their hair using dreadlocks. That is the effect of hip hop imperialism imported from the United States to various countries. According to Tomlinson, cultural imperialism causes cultural homogenization and uniformity, which will make one culture dominate other 
cultures (Tomlinson, 2002). Furthermore, paradoxically cultural imperialism also provides benefits to Asian rappers. Because with Asian people who become rappers, the Asian community, especially those in western circles such as immigrants in the United States, feel represented by Asian hip hop artists' existence. Also, Asian rappers can instantly introduce their culture of origin globally.

In other words, American cultural imperialism does not always harm other cultures. It gives the advantages for Asian rappers for their careers in hip hop industry to enter the market globally and to represent their identity in the West. This hybrid culture also makes people such as immigrants, predominantly Asian immigrants in the United States, connect with what is represented by Asian rappers. Moreover, Asian hip hop culture in the United States is not only about consumerism but also about the representation of certain ethnicities that live in the United States.

\section{REFERENCES}

Barker, C. (2008). Cultural Studies: Theory and Practice. London: SAGE Publication.

Bynoe, Y. (2002). Getting Real about Global Hip Hop. Georgetown Journal of International Affairs, 79.

Creswell, J. W. (2013). Research Design. Qualitative, Quantitative, and Mixed Methods Approaches. California: Sage Publication, Inc.

Dasfriana, D. A. (2019). Komodifikasi dan Universalisme Budaya dalam Asian Hip Hop di Amerika Serikat oleh 88rising. Bandung: Universitas Katolik Parahyangan.
Forman, M. (2010). Conscious Hip-Hop, Change, and the Obama Era. American Studies Journal, 1-20.

Glasby, T. (n.d.). “Cover Story: Rich Brian's Glow Up. Retrieved from Crack Magazine.:

https://crackmagazine.net/article/longreads/rich-brians-glow-up/

Glasby, T. (2017, February 14). Meet Kohh, Japan's most enigmatic rap star. Retrieved from Dazed: https://www.dazeddigital.com/music/ar ticle/34695/1/kohh-japanese-rapper

Hesmondhalgh, D. (1995). Global Popular Music, Cultural Imperialism and The English Language. LIN:Q, 44-64.

Kalisu, M. Y. (2017). Perkembangan dan Self Image Dalam Musik Hip Hop Di Jepang. Makassar: Universitas Hasanuddin.

Kraidy, M. M. (2002). Hybridity in Cultural Globalization. Annenberg School for Communication, 1.

Lee, C. (2018, February 1). As Asian rappers rise, some must face questions about race and hip-hop. Retrieved from NBC News:

https://www.nbcnews.com/news/asianamerica/asian-rappers-rise-some-mustface-questions-about-race-hip-n843416

Leonard, D. (2017). This Man Sold the World on Asian Hip-Hop. Retrieved from Bloomberg.com: https://www.bloomberg.com/news/feat ures/2017-12-05/the-man-who-soldthe-world-on-asian-hip-hop

Pareles, J. R. (2015). All the Best Concerts, of What the Critics Have Seen. Retrieved from NYTimes: https://www.nytimes.com/2015/12/30/a 
rts/music/all-the-best-shows-of-what-

the-critics-have-seen.html?_r=1

Pieterse, J. N. (2009). Globalization and

Culture: Global Melange. United

Kingdom: Rowman \& Littlefield

Publishers, INC.

Said, E. (1994). Culture and Imperialism. Vintage Publishers.

Schiller, H. (1976). Communication and Cultural Domination. New York: International Arts and Sciences PressChris.

Tai, C. (2018, May 28). Asian hip hop: an homage to a genre or cultural appropriation driven by racism or ignorance? Retrieved from South China Morning Post: https://www.scmp.com/lifestyle/fashio n-beauty/article/2148143/asian-hiphop-homage-genre-or-culturalappropriation-driven

Tomlinson, J. (2002). Cultural Imperialism: A Critical Introduction. London: Continuum.

Zhang, H. (2018). A Study of '88rising' and their YouTube Approach to Combine Asian Culture with the West. Dublin: University of Dublin. 